\title{
BUDDHIST ART MONUMENTS IN UZBEKISTAN
}

\author{
Eshmamat Haitov
}

Associate Professor National Institute Of Fine Arts And Design Named After Kamoliddin Behzod Tashkent, Uzbekistan

\section{ABSTRACT}

This article is devoted to the coverage of the earliest ideas and concepts of Buddhist art monuments in Uzbekistan on the basis of existing scientific sources.

KEYWORDS:- Buddhist art, great silk road, nirvana, shakyamuni, wheel, lotus flower, stupa, bodhisattva, statue of monks, fayoz-tepe, dalverzin-tepe, ayritom, kampir-tepe, kara-tepe.

\section{INTRODUCTION}

The historical significance and influence of the Great Silk Road on the development of Uzbekistan's fine and applied arts is unrivaled. Buddhism's relics and masterpieces of art created on its foundation, which entered through this caravan route that connected East and West artistic culture for centuries, are still partially preserved (1). According to sources, Buddhism entered the Kushan Empire through the Great Silk Road at the end of the 1st millennium BC, covering a large area from Central Asia to India. Archaeological excavations of Shakyamuni statues, animal statues, symbolic wheels, and stupa remains in Uratepa, Dalverzin-Tepe, Quva, Zartepa, Qorovul-Tepe, Ayritom, and Fayoz-Tepe confirm the importance of Buddhism in the Kushan Empire (3).

\section{Methods AND Materials}

In the fine arts, particularly sculpture, there are so many Buddhist works. The Buddha and Bodhisattva statues found in the Dalverzin-Tepe temple of the first and second centuries, in particular, support this conclusion (11). In terms of size, processing techniques, and appearance, these sculptures differ from those of other regions. Some of them were made to be three meters or higher. The body of the bodhisattva, in contrast to the image of the Buddha, is adorned with precious jewels - bracelets on the hands and earrings on the ears. Such a distinction acquires a symbolic meaning. That is, this image was created as a sign that the followers of the Buddha had not yet completely renounced the pleasures of life (5).

All the statues found in the temple are painted in distinctive red, pink and blue colors. But their backs, which are attached to the wall, appear to be ignored. Presumably, the sculptures were made of a wood-based primary semi-finished product, which was then covered with clay. The tops of all the statues were plastered with multiple layers, and the exact bodies and their faces were made. After that, the appearance of the image-the clothes and the head-were processed. According to scientists, such 
CURRENT RESEARCH JOURNAL OF HISTORY 2(5): 01-05, May 2021

DOI: https://doi.org/10.37547/history-crjh-02-05-01

ISSN 2767-472X

(C)2021 Master Journals

\section{Crossref do) 81 Google}

Accepted 15 th May, 2021 \& Published 20 ${ }^{\text {th }}$ May, 2021

processing techniques and imagery are typical of Bactrian sculptors, as this has also been observed in sculptures found in several monuments of Bactria (11).

We can see the only famous image of the Buddha with his monks around him in the embossed images of the Buddha found in Fayoz-Tepe (old Termez) and in the embossed murals of the I-II centuries. Unlike others, it was made of marblelike limestone. It was created using a placement method in a columnar style composition that was unnatural for local sculpture (5).

According to archaeologist Bohodir Turgunov, the art of Buddhism gradually began to emerge under the influence of this religion and in the process of propagating its ideas. Art samples from the early period of Buddhism depicted various symbols (such as the wheel, the lion, the sacred idol tree) based on the ancient Hindus' notions of celestial bodies instead of the Buddha. The depiction of the Buddha in human form appeared only in the art of Gandhara and Mathuri in the early AD. Later, in many countries, in the art of sculpture and painting, symbolic images of different sizes were created. The main figure in Buddhist art is Prince Sitdharta Gautama, the founder of Buddhism, who is depicted in works of art mainly in three situations:

The standing Buddha is a preacher;

The seated Buddha is a contemplative thinker;

The lying Buddha is a Buddha who has passed away. (10)

Ancient monuments of Buddha-related art have emerged in India. The range of symbols and images, Buddhist buildings - cave temples, which created a unique harmony of architecture, sculpture, and fine arts, stupas that built in honor of the legendary events of the life of the Buddha that preserving the sacred monuments, cave temples and stupa-like monuments (pagada, dagob, suburgan and etc.) were common in other countries. Various types of wooden temples were built in China, Japan, and Korea, and along with monumental painting in the context of Buddhism, bench painting also developed. In Indonesia, Cambodia, and other countries, stone temples and temple ensembles associated with Buddhism; in India, Burma, and Nepal, monastery complexes; in Tibet, Mongolia, Buryatia, and other regions, lomanism monastery ensembles emerged.

\section{Results AND DISCUSSION}

It was discovered that the people who lived in the Kushan kingdom's territory believed in Buddhism as well as other religions. This is confirmed by the fact that Kushan coins depict Buddhist figures (5).

Monumental buildings (mostly the construction of Buddhist monasteries), which were decorated with statues and murals, played a major role in Buddhist art. In Ayritom, an underground monastery (sangarama), in Kara-Tepe, cave temple (vihara), in Chingiz-Tepe and DalverzinTepe, the remains of a complex of ancient cave monasteries were found. These also include limestone carved plaster, clay sculptures, colorful murals, and other artifacts related to Buddhist art. In particular, the Zurmala Tower is a remnant of the Buddha Stupa, which is believed to have been three-storied. Samples of Buddhist art were similar in form and content regardless of where they were found (10).

Between the 1st century BC and the 4th century AD, the Kushan Empire announced Mahayana Buddhism as the state religion. Although Buddhism had a long history in India before that, Hinayana, which was the main direction there, had not achieved such a position. Kanishka, Vima, Kadphises, and the subsequent Kushan emperors, spread Buddhism widely. They built 
CURRENT RESEARCH JOURNAL OF HISTORY 2(5): 01-05, May 2021

DOI: https://doi.org/10.37547/history-crjh-02-05-01

ISSN 2767-472X

(C)2021 Master Journals

\section{Crossref do) 81 Google}

Accepted 15th May, 2021 \& Published 20th May, 2021

Buddhist temples, khanaqahs, and temples in Balkh, Merv, Termez, Samarkand, Bukhara, Shosh, Turkestan, Kuva, Kasan, Osh, Bolasogun, Kashgar, and other cities in order to develop these religious traditions in practice and spread them among other peoples. They also created the conditions for the study, translation, and interpretation of the sacred books of Buddhism and the sutra vapostoris. As a result, the basic ideas of this religion began to become extremely popular in these areas, gaining a great position among the local population.

A lot of pottery was found in Qoratepa. The inscriptions on them belong to the teachings of Mahasanghika. This school played an important role in the spread of Buddhism in our country. The inscriptions in the Brahma script in another part of Qoratepa came a little later, in the Kanishka period (6).

In the III-I centuries BC, Buddhism spread beyond India in the form of the Hinayana doctrine in a south-easterly direction. But at the beginning of the century $\mathrm{AD}$, it moved north, northwest, and northeast in a Mahayana style. The reason for this was that for several centuries, the territories of Northern India, Central Asia, were united under the banner of a single Kushan kingdom. There is speculation that Buddhism entered the Far East through Central Asia and began its second life.

Many monuments of fine arts and historical monuments of Buddhism have been found in our country. Among them, the religious complex found in Fayoztepa is one of the largest in Uzbekistan. The area of the temple, along with the religious inscriptions and statues found there, occupied a much larger area (7).

The "Zurmala Tower" in the east of the old Termez, discovered in 1926 during archeological excavations, is mentioned as the first and most important cultural monument in our country (6).
Remains of the Kara-Tepa Buddhist complex have been found on the site of the old Termez ruins in the Surkhandarya region. Each structure in this monument, which dates from the first century AD, the heyday of the Kushan Empire, is located above ground and in a cave (7). It is assumed that the Buddhist temple built in it consisted of a main hall, a room adapted for a servant-a monk.

One of the main sects of Buddhism is the Hinayana direction. Hinayana means 'small wheel'. It was established as an official religious direction in the first century BC. However, its basic rules have been stated long ago, including in Tripitaka.

Hinayana emphasizes that the study of the nature of dharma and the attainment of nirvana is a spiritual path. This path is very difficult and only monks can reach the state of nirvana. Later, very complex and lavish prayers (e.g., "worship of the Buddha's tooth") were introduced in the hinayana, and public visits to Buddhist shrines were introduced. This route was widespread in eastern India, Sri Lanka, and Indo-Chinese countries.

"In ancient architecture, the practical decorative part of the column, which was included in the order system, is called the capital. The capitals served to distribute the load falling on the girder evenly over the columns. They were originally made of wood. Under the influence of Greek architecture, they began to be made of stone. In Bactrian architecture, the presence of ionic vascorphic species of stone capitals has also been identified. The main element of ionic capital - the gajak, which is turned down by its two sides - are currencies. In addition to their aesthetic significance, currencies also have symbolic meanings. There is a belief among people that comparing them to sheep (goat) horns protects a building or structure from evil forces. Currencies also come in the form of a spiral. Gajak has 
CURRENT RESEARCH JOURNAL OF HISTORY 2(5): 01-05, May 2021

DOI: https://doi.org/10.37547/history-crjh-02-05-01

ISSN 2767-472X

(C)2021 Master Journals

\section{Crossref do) 81 Google}

Accepted 15th May, 2021 \& Published 20 th May, 2021

symbolic meanings such as origin, expansion, development, periodicity, and continuous duration. It represents the practice of force and motion that emerges from the center and leads to infinity. Gajak is considered to be the moon, fertility, life expectancy, duration of gradual development (8).

The lotus can also be found among the less common themes in the capitals. The theme of the lotus has existed in the eastern peoples since ancient times. Its semantics are different. Especially among the Egyptians, the lotus leaf was recognized as a symbol of goodness, light and love. The lotus also appears as a symbol of the universe (the sun). The lotus was given special attention in Buddhism. It symbolized the divine birth and belonging to the Buddha, that is, the "miracle of the birth of the Buddha." This is why the image of the lotus leaf was so common in Buddhist art. Ceramic vessels, relics (vessels used in religious ceremonies) lids were decorated with lotus leaves. Lotus flowers are also found in murals. Stupa platforms, the base of Buddhist statues, thrones and other architectural pieces were decorated with them. According to Sh.R.Pidaev, the depiction of twelve lotus leaves in the capital of Termez is significant in that it represents the state of nirvana. This is another example of how the concept of Buddhism influenced all aspects of Kushan Bactrian art (11). Human images in Ayritom friezes have been interpreted in the scientific literature as gifts or charitable donors. Due to the fact that frieze was used in Buddhist construction, it was noted that they were associated with a Buddhist theme, while the images represented themes in Buddhist mythology (11).

\section{Conclusion}

As a result, many statues and murals have been erected based on Buddhist teachings and some of its legends. These masterpieces of art deserve special scientific study in the history of art in Uzbekistan. At the same time, the fact that it is mentioned among the ancient Chinese and Indian civilizations also testifies to the importance and place of the Great Silk Road in its historical development.

\section{REFERENCES}

1. Ibrokhim Rahimovich Abdurakhmonov. Concept of mythology represented in the fine arts of Uzbekistan.-//Asian Journal of Multidimensional Research. Impact Factor: SJif $2020=6.882$. Vol.9, Issue 10, October 2020. P.143-147.

2. Ibragim Abdurakhmonov. Reflection of Written Dastans in Maveraunnahr Miniature (XIV-XVII Centuries) .-//International journal of research. With Impact Factor 5.60. 2018. P.425-432.

3. Ibrokhim Abdurakhmonov. Painter of Folk Poems.-//San'at, 2018. №:2. P.31-35.

4. Ibrokhim Abdurakhmanov. (2019) "Specific peculiarities and value of legendary themes in practical art," Culture and Arts of Central Asia: Vol.10. No:1, Article 12. Available at: https://uzjournals.edu.uz/cacenas/vol10/is s1/12.

5. Ibrahim Abdurahmonov. Painter of Folk Poems.-//San'at, 2018. №:2. P.31-35.

6. Ibrakhim Abdurakhmonov $\mathrm{He}$ Interpretation Of Images On Dualism, Totemisv, Animism And Fetishism. The American Journal of Social Science and Education Innovations (ISSN-2689-100X). Impact Factor. 2021.5.857. P. 75-81.

7. Antiquities of Southern Uzbekistan. //Catalog. Tokyo/1991. pp. 11-25. 5. 
8. Kenzo Kawasaki. Buddhist visual arts. Northern Bactria-Tokharistan I-IV centuries AD T., 1999

9. Dalvarzintepa city. In Uzbek and Japanese languages. Tokyo., 1996. Pages 188-191.

10. StavitskyB.Ya. The fate of Buddhism in Central Asia.-Moscow., 1998

11. Termiz. Album-monograph. An article on Buddhism in Termez. T.: Sharq.2001.-Pages 57-62.

12. Rtveladze E. Diplomacy in the Great Silk Road. (In the book of the Great Silk Road). T, National Encyclopedia of Uzbekistan Publishing House., 2010. Pages 259-168.

13. National Encyclopedia of Uzbekistan.-I volume, T., $2000.142 \mathrm{p}$.

14. Turgunov B. Buddhist art. National Encyclopedia of Uzbekistan T., Volume 2. Pages 232-233.

15. Pidaev Sh. Buddhism and Buddhist heritage in ancient Uzbekistan.-T, Uzbekistan., 2011.

16. Kurbanova, D. A. (2016). ANCIENT PEARLS IN GREAT WORLD MUSEUMS WHICH BELONG TO THE HISTORY OF UZBEKISTAN AND LEARNING THEM. Социосфера, (3), 55-61.

17. Sayfullaev, N. (2021). The Name Of Our Country Will Be Praised By The Followers Of Kamoliddin Bekhzod. The American Journal of Social Science and Education Innovations, 3(04), 402-408. 